\title{
PENGEMBANGAN MEDIA VIDEO TUTORIAL PADA MATA KULIAH TEKNOLOGI MENJAHIT DALAM MENDUKUNG PEMBELAJARAN DIMASA PANDEMI COVID-19
}

\author{
Erni $^{1)}$, Farihah ${ }^{2)}$ \\ ${ }^{1}$ Fakultas Teknik, Universitas Negeri Medan \\ 2 Fakultas Teknik, Universitas Negeri Medan \\ Email: erni_ernihanafi@unimed.ac.id, farihah_farihah34@gmail.com
}

\begin{abstract}
ABSTRAK
Pandemi Covid-19 membawa dampak yang cukup signifikan terhadap proses belajar mengajar. Didasari perubahan cara belajar secara luring menjadi daring baik pada mata kuliah teori maupun praktik, tentu perlu mendapatkan perhatian khusus dalam proses penyampaian materi perkuliahan. Oleh karena itu perlu adanya pengembangan media khusus yang dapat dipelajari oleh mahasiswa secara mandiri. Penelitian ini bertujuan merancang, mengimplementasikan, mengetahui kelayakan media, kepraktisan media dan keefektivan media serta respon mahasiswa terhadap pengembangan media video tutorial pada mata kuliah teknologi menjahit untuk materi cara mengoperasikan mesin jahit. Video ini dikembangkan guna mendukung pembelajaran daring dimasa pandemic virus corona. Pengembangan media video tutorial menggunakan model pengembangan 4-D melalui 4 tahapan yaitu tahap Define (pendefinisian), tahap Design (perancangan), tahap Development (pengembangan) dan tahap Disseminate (menyebarkan). Penelitian dan pengembangan ini melalui tahap uji validitas, uji praktikalitas dan uji efektifitas. Hasil penelitian terhadap uji validitas oleh ahli materi dan ahli media dengan skor 3.75 pada rerata $3.20-4.00$, maka aspek yang dinilai dikategorikan sangan jelas atau "Sangat valid". uji praktikalitas sebesar $89.1 \%$ dengan kategori "Sangat praktis". dan uji efektifitas pada faktor motivasi balejar mahasiswa sebesar $85.12 \%$ dengan kategori "Sangat tinggi" dan hasil belajar psikomotor mahasiswa dengan perolehan nilai 80 dengan kriteria "Baik".
\end{abstract}

Kata kunci: video tutorial, teknologi menjahit, pembelajaran daring

\begin{abstract}
The Covid-19 pandemic has had of significant impact on the teaching and learning process. Based on the change in the way of learning offline to online both in the theoretical and practical course, of course it needs special attention in the process of delivering lecture material. Therefor it necessary to develop special media that can be studied by students independently. This study aims to design, implement, determine the feasibility of the media, the practicality of the media and the effectiveness of the media as well as student response to the development of video tutorial media on sewing technology courses for material on how operate sewing machines. This video was developed to support online learning during the corona virus pandemic. The development of video tutorial-based learning media uses a 4-D development model through 4 stages, namely the Define stage, the Design stage, the Development stage and the Disseminate stage. This research and development goes through the validity test, practicality test and effectiveness test. The results of the research on the validity test by material experts ang media experts with a score of 3.75 on a mean of $3.20-$ 4.00 , then the aspect assessed were categorized as very clear or "Very valid", practicality test of $89.1 \%$ with the category "Very practical" and the effectiveness test on student motivation factor of $85.12 \%$ with the "Very high" category, and student psychomotor learning outcomes with a score of 80 with "Good" criteria.
\end{abstract}

Keywords: video tutorials, sewing technology, online learning 


\section{PENDAHULUAN}

Mata kuliah teknologi menjahit merupakan salah satu mata kuliah wajib di Program Studi Pendidikan Tata Busana Universitas Negeri Medan. Mata kuliah ini diprogramkan disemester pertama dengan bobot 3 SKS yang terdiri dari 20\% teori dan $80 \%$ praktik. Mata Kuliah ini diberikan pada mahasiswa semester I, yang berisikan konsep teoritis dan praktek dasar menjahit busana. Materi mata kuliah ini meliputi; 1). Piranti alat jahit, 2). Cara mengoperasikan mesin jahit secara manual, elektrik dan industri, 3). Teknik menjahit bermacam-macam tusuk, 4). Taknik Menjahit bermacammacam kampuh, 5). Pembuatan lajur, lipit, 6). Penyelesaian tepi pakaian (serip, rompok, depun, kelim), 7). Pembuatan saku, 8). Pembuatan kerah, 9). Pembuatan Lengan, 10). Teknik pemasangan renda, 11). Bermacam-macam belahan, 12). Teknik memasang kancing dan rumah kancing. (Silabus Prodi Pendidikan Tata Busana). Semua teknik menjahit yang dipelajari disemester ini nantinya akan diterapkan dalam menciptakan sebuah busana dan mata kuliah ini juga berkontribusi pada mata kuliah praktikum lainnya. Dengan materi perkuliahan yang terbilang banyak, kompetensi utama yang perlu dikuasi oleh mahasiswa yang memprogramkan mata kuliah ini yaitu cara mengoperasikan mesin jahit.

Dimasa pandemic virus corona, semua kegiatan belajar mengajar berlangsung secara daring. Bagi mahasiswa yang lulusan SMK bidang tata busana, tentu bukan perkara sulit untuk dapat mengoperasikan mesin jahit dengan baik dan benar. Namun sebagaimana diketahui bahwa lebih dari setengah jumlah mahasiswa baru Angkatan 2020/2021 merupakan lulusan dari berbagai sekolah menengah atas/sederajat dan bukan mayoritas lulusan SMK Tata Busana. Kondisi ini dirasa perlu mendapat perhatian khusus agar mahasiswa tersebut dapat menerima pembelajaran dengan baik dan dapat menyelesaikan tugas-tugas yang dibebankan pada mata kuliah ini. Hal ini bermula dari kompetensi mengoperasikan mesin jahit agar mahasiswa dapat melanjutkan ke materi pembelajaran selanjutnya.

Pembelajaran yang berlangsung secara daring memerlukan media yang dapat dipelajari secara mandiri oleh mahasiswa. Dimana penggunaan media pembelajaran yang adaptif dan berkualitas merupakan salah satu cara guna mewujudkan proses belajar yang menyenangkan dan mencapai tujuan pembelajaran [1]. Media pembelajaran merupakan sarana ataupun instrument yang mendukung efektivitas maupun efisiensi kegiatan belajar mengajar, terlebih ketika proses pembelajaran dlharuskan berlangsung dari rumah selama masa pendemi Covid-19 [2]. Pendapat ini sejalan dengan [3] menjelaskan bahwa dalam belajar siswa juga perlu didukung oleh strategi pembelajaran yang tepat sehingga siswa dengan mudah memahami konsep dan mencapai hasil belajar yang memuaskan. Dalam masa pandemic covid-19 ini media pembelajaran seperti video pembelajaran menjadi sangat urgen diperlukan guru dan siswa

Lebih lanjut, untuk mendorong proses pembelajaran yang efektif dan efisien, media pembelajaran harus berfungsi sebagai alat komunikasi yang digunakan untuk menyampaikan pesan sehingga dapat meransang pikiran, perasaan dan kemampuan mahasiswa [4]. Penggunaan media yang tepat, dapat membantu mahasiswa dalam menguasai materi perkuliahan yang diberikan. Terlebih saat ini proses pembelajaran praktikum berlangsung secara daring. Hal ini menuntut setiap mahasiswa untuk lebih dapat belajar mandiri sebagaimana konsekuensi dari pembelajaran daring.

Seiring perkembangan IImu Pengetahuan dan Teknologi dalam bidang Pendidikan, maka sistem pendidikan berorientasi media elektronik. Penerapan IImu Pengetahuan dan Teknologi dalam pendidikan, tentunya akan menghasilkan sistem pembelajaran berorientasi teknologi, khususnya media pembelajaran. Saluran atau perantara yang dapat digunakan untuk menyampaikan pesan (bahan pembelajaran) sehingga dapat merangsang perhatian, minat, pikiran, dan perasaan pembelajar (mahasiswa) dalam kegiatan belajar untuk mencapai tujuan pembelajaran tertentu merupakan makna dari media pembelajaran.

Pada perkuliahan teknologi menjahit, praktik yang dilakukan kemudian berlanjut latihan oleh mahasiswa yang membutuhkan contoh dan langkah kerja yang memudahkan mahasiswa dalam mempraktikkan materi yang diberikan. Media yang dapat memberikan gambaran secara lengkap perihal langkah kerja praktikum dan dapat disaksikan secara berulang-ulang yaitu video tutorial. Untuk lebih jelasnya, video adalah alat yang mampu menampilkan pemaparan proses, penyajian informasi, penjelasan konsep yang rumit, mengajarkan keterampilan, mempersingkat dan memperlambat waktu.

Penggunaan media video tutorial dalam perkuliahan mempunyai nilai-nilai praktis, [5] menyatakan sebagai berikut: 1) Mengatasi keterbatasan jarak dan waktu; 2) Video dapat diulangi bila perlu untuk menambah kejelasan; 3) Pesan yang disampaikannya cepat dan mudah diingat; 4) Mengembangkan pikiran dan pendapat mahasiswa; 5) Mengembangkan imajinasi peserta didik; 6) Memperjelas hal-hal yang abstrak dan memberikan gambaran yang lebih realistik;7) Sangat kuat 
mempengaruhi emosi seseorang;8) Sangat baik menjelaskan suatu proses dan keterampilan, mampu menunjukkan rangsangan yang sesuai dengan tujuan dan respon yang diharapkan dari mahasiswa; 9) Semua peserta didik dapat belajar dari video, baik yang pandai maupun kurang pandai; 10) Menumbuhkan minat dan motivasi belajar; 11) Dengan video penampilan mahasiswa dapat segera dilihat kembali untuk dievaluasi.

Video pembelajaran sebagai media yang digunakan untuk merangsang pikiran, perasaan, dan kemauan mahasiswa untuk belajar melalui penayangan ide atau gagasan, pesan dan informasi secara audio visual. Dengan adanya media audio visual, siswa dapat melihat secara langsung tindakan nyata dari apa yang tertuang dalam media tersebut, hal ini dapat merangsang motivasi belajar mahasiswa dan meningkatkan aktivitas belajar mahasiswa.

Tutorial adalah pembimbingan yang dilakukan oleh seorang pengajar kepada sekelompok mahasiswa. Video tutorial merupakan rangkaian gambar hidup yang ditayangkan oleh seorang pengajar kepada peserta didik yang berisi pesan-pesan pembelajaran guna memberikan pemahaman terhadap suatu materi sebagai bimbingan atau bahan pembelajaran kepada sekelompok peserta didik [6]. Video tutorial memiliki kelebihan yaitu tampilannya menarik perhatian, dengan perekaman video beberapa penonton memperoleh informasi dari ahlinya, demonstrasi biasanya sulit disiapkan dan direkam, pada waktu belajar dosen dapat memusatkan perhatian mahasiswa pada penyajiannya, efisiensi waktu dan rekaman yang sudah dibuat dapat diputar ulang, dapat mengamati objek, lebih dekat dengan objek yang sedang bergerak, keras atau lemahnya suara bisa disesuaikan, gambar proyeksi bisa dibekukan (pause) untuk mengamati gambar dengan seksama [7].

Mengacu pada uraian diatas, guna mendukung pembelajaran daring dimasa pandemic Covid19 dibutuhkan pengembangan media yang dapat disaksikan secara berulang-ulang oleh mahasiswa agar mahasiswa dapat mencapai kompetensi yang diharapkan pada mata kuliah teknologi menjahit. Oleh karena itu penelitian ini dilakukan dengan tujuan untuk mengembangkan media berbasis video tutorial pada mata kuliah teknologi menjahit serta untuk mengetahui validitas, praktikalitas dan efektivitas media video tutorial pada mata kuliah teknologi menjahit dalam mendukung pembelajaran daring dimasa pandemic Covid-19.

\section{METODE}

Metode merupakan suatu proses atau cara yang harus di lalui untuk melakukan penelitian. Penelitian dan pengembangan ini dilakukan di Universitas Negeri Medan. Subjek pada penelitian ini adalah mahasiswa semester 1 Program Studi Pendidikan Tata Busana Angkatan 2020/2021 kelas B dengan jumlah 38 orang. Obyek penelitian ini adalah video tutorial pada mata kuliah Teknologi Menjahit. Metode penelitian dan pengemabangan adalah metode yang digunakan untuk menghasilkan produk tertentu [8]. Selanjutnya metode $R \& D$ merupakan suatu penelitian yang dilakukan untuk pembuatan produk baru maupun mengembangkan produk yang sudah kemudian dilakukan uji efektifitas produk agar dapat digunakan dalam proses pembelajaran [9].

Langkah-langkah penelitian dan pengembangan terdiri dari Define, Design, Development dan Dissemination yang disingkat dengan 4D [10]. Tahap 1 Define, adalah merumuskan masalah yang terdapat pada latar belakang serta menganalisis tujuan penelitian. Tahap 2 Design, adalah membuat rancangan awal produk yang akan dikembangkan, seperti penyusunan data dan materi serta pembuatan skenario yang dilanjutkan dengan take gambar dan editing. Tahap 3 Development, yaitu tahap melakukan penilaian dan evaluasi oleh ahli materi, ahli media, dan mahasiswa serta menganalisis hasil penilaian kemudian dilakukan perbaikan/revisi produk untuk memperoleh produk akhir. Tahap 4 Disseminate, adalah penyebarluasan produk agar dapat dimanfaatkan oleh banyak orang [11].

Analisis validitas diperoleh menggunakan lembar validasi, data praktikalitas diperoleh dengan menggunakan angket praktikalitas, sedangkan data efektivitas diperoleh dengan menggunakan lembar pengamatan hasil belajar psikomotor. Data yang diperoleh dari penelitian ini adalah data kualitatif dan kuantitatif. Data kualitatif berupa kritik dan saran dari ahli media dan ahli materi, sedangkan untuk data kuantitatif berupa data kelayakan media. Langkah-langkah pengembangan media disajikan dalam bentuk diagram berikut: 


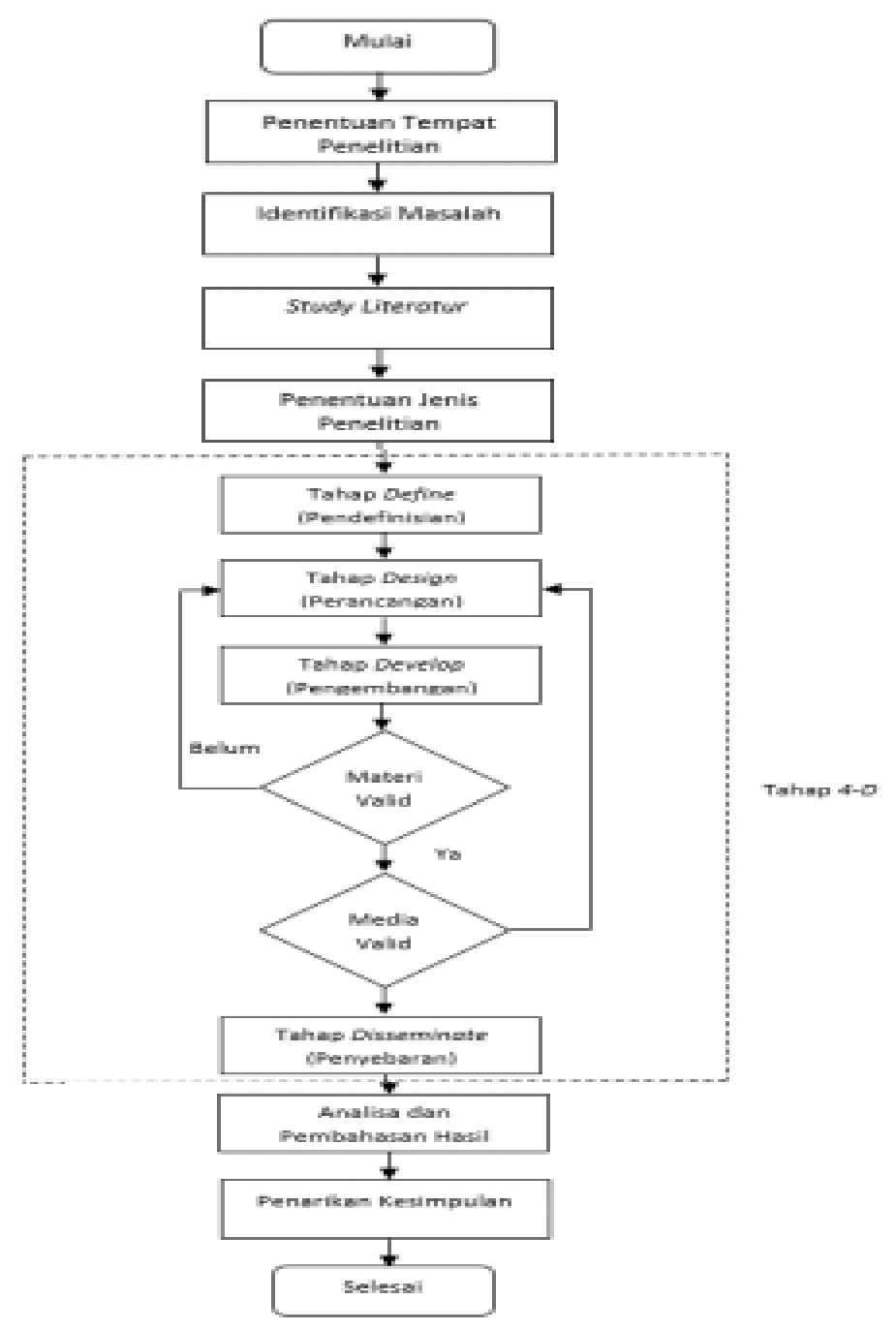

Gambar 1. Metode Penelitian 4-D Sumber [12]

\section{HASIL DAN PEMBAHASAN}

Penelitian pengembangan media video tutorial pada pada kuliah teknologi busana dikembangkan dengan menggunakan model 4-D, dalam proses pengembangannya melalui 4 (empat) tahapan, yaitu; Define (pendefinisian), Design (perancangan), Developement (pengembangan), Disseminate (penyebaran). Tahap Define (pendefinisian) kegiatan yang diawali dengan menganalisis Silabus Teknologi Menjahit untuk menetapkan produk yang akan dikembangkan dan spesifikasinya. Peneliti melakukan diskusi dengan dosen pengampu mata kuliah teknologi menjahit untuk melakukan analisis, mengenai:

a. Analisis kebutuhan dosen dan mahasiswa

b. Analisis silabus

c. Analisis materi

Tahap anailisis kebutuhan dosen dan mahasiswa digunakan untuk mengidentifikasi kebutuhan dalam mata kuliah teknologi menjahit yang merupakan mata kuliah praktikum. Dikarena pembelajaran berlangsung secara daring, dibutuhkan media yang dapat dipelajari secara mandiri dan dapat disaksikan secara berulang oleh mahasiswa. Analisis silabus dilakukan untuk menganalisis materimateri yang akan diberikan kepada mahasiswa dalam satu semester. Analisis materi yaitu menentukan kompetensi utama yang wajib dikuasi oleh mahasiswa.

Tahap pendifinisian dilakukan dengan berdiskusi dengan dosen pengampu mata kuliah teknologi menjahit. Hasil diskusi memutuskan untuk mengembangkan video tutorial pada materi cara 
mengoprasikan mesin jahit. Materi ini dipilih karena kompetensi ini merupakan kompetensi dasar yang harus dikuasi oleh mahasiswa Pendidikan Tata Busana.

Tahap Design (perancangan) tahap ini berisi kegiatan untuk merancanag produk yang telah ditetapkan. Kegiatan ini diawali dengan membuat kisi-kisi video tutorial. Selanjutnya menyusun scrip video tutorial sesuai kisi-kisi yang telah ditetapkan, diantaranya; Logo Universitas Negeri Medan, kata pengantar mata kuliah, pengenalan alat dan bahan untuk menjahit, urutan pemasangan komponen mesin jahit, cara menjahit pada kertas tanpa menggunakan benang jahit serta cara menjahit pada kain dengan menggunakan benang jahit dengan pola jahit lurus, pola jahit patah-patah dan pola jahit melengkung. Kemudian melakukan proses perekaman gambar, perekaman suara dan proses editing video tutorial. Dilanjutkan dengan mengupload video tutorial ke layar YouTube.

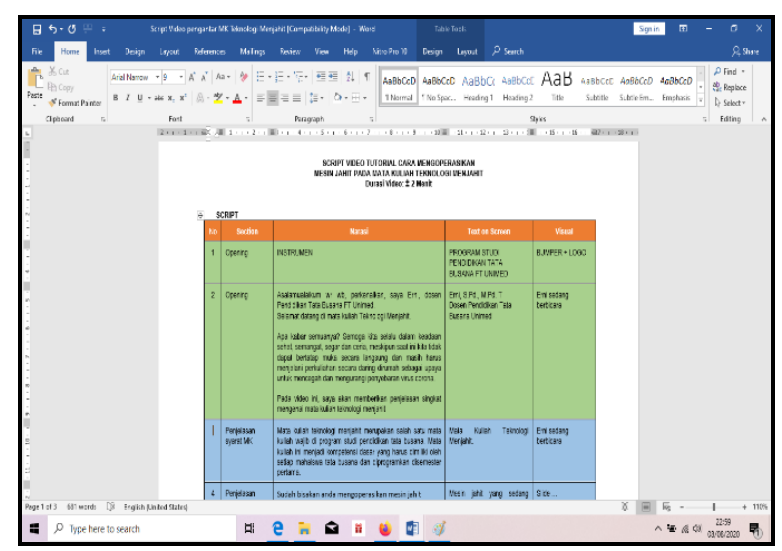

Gambar 2. Tampilan scrip video tutorial cara mengoperasikan mesin jahit

Gambar 2 merupakan scrip video tutorial yang memuat Nomor urutan perekaman video tutorial cara mengoperasikan mesin jahit. Section (bagian) berisi opening (pembuakaan), penjelasan syarat mata kuliah, deskripsi mata kuliah, tujuan mata kuliah, capaian mata kuliah, menu utama dan menu penutup. Narasi, berisi skenario video tutorial. Text on screen berisi tampilan teks pada layar video tutorial. Visual berisi logo Universitas Negeri Medan, menampilkan peneliti sedang berbicara dan memperagakan cara memasang komponen mesin jahit serta peneliti memperagakan cara mengoperasikan mesin jahit dengan baik dan benar.

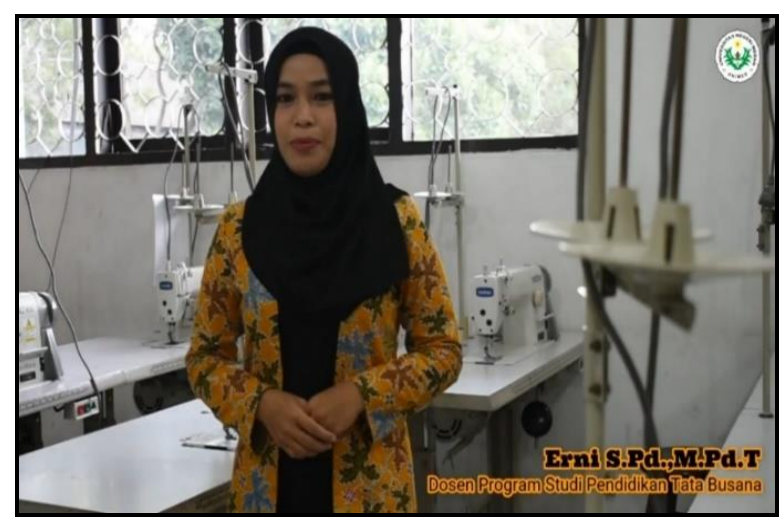

Gambar 3. Tampilan scrip video tutorial cara mengoperasikan mesin jahit

Gambar 3 menampilkan peneliti sedang memperkenalkan diri. Pada menu utama ini diawali dengan menampilkan logo universitas, menampilkan Fakultas Teknik, manampilkan Laboratorium Tata Busana yang disertai dengan background musik yang ringan. Pada tampilan ini peneliti menyapa mahasiswa dengan ramah dan bersemangat serta memberikan kata pengantar mata kuliah. Pengantar mata kuliah berisikan penjelasan singkat mengenai mata kuliah teknologi menjahit, tujuan mata kuliah teknologi menjahit, capaian mata kuliah teknologi menjahit dan menyampaikan motivasi untuk mahasiswa. 


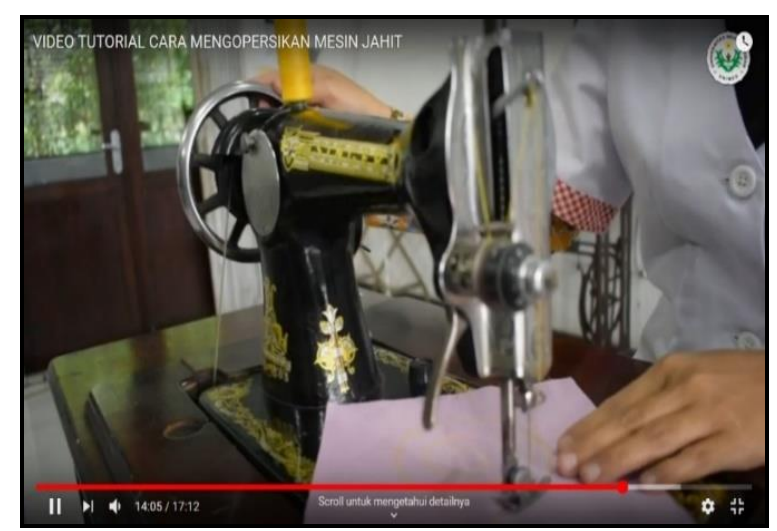

Gambar 4. Tampilan menu utama cara mengoperasikan mesin jahit

Gambar 4 merupakan tampilan menu utama pada video tutorial teknologi menjahit yang berisi tahapan dalam menjahit mulai dari persiapan alat dan bahan menjahit, memasang komponen mesin jahit secara berurutan dan cara mengoperasikan mesin jahit dengan baik dan benar. Tahapan mengoperasikan mesin jahit dengan latihan menjahit pada selembar kertas yang telah diberi garis sebagai acuan dalam melihat laju mesin jahit. Latihan pada kertas ini dilakukan tanpa menggunakan benang jahit, kemudian dilanjutkan dengan menjahit pada kain menggunakan benang jahit. Adapun pola jahit untuk melatih cara mengoperasikan mesin jahit yaitu menjahit pada pola jahit lurus, menjahit pada pola jahit patah-patah dan menjahit pada pola jahit melengkung. Video tutorial ditampilkan dengan gambar bergerak, suara dan teks sebagai keterangan penjelasan mengenai tahapan mengoperasikan mesin jahit.

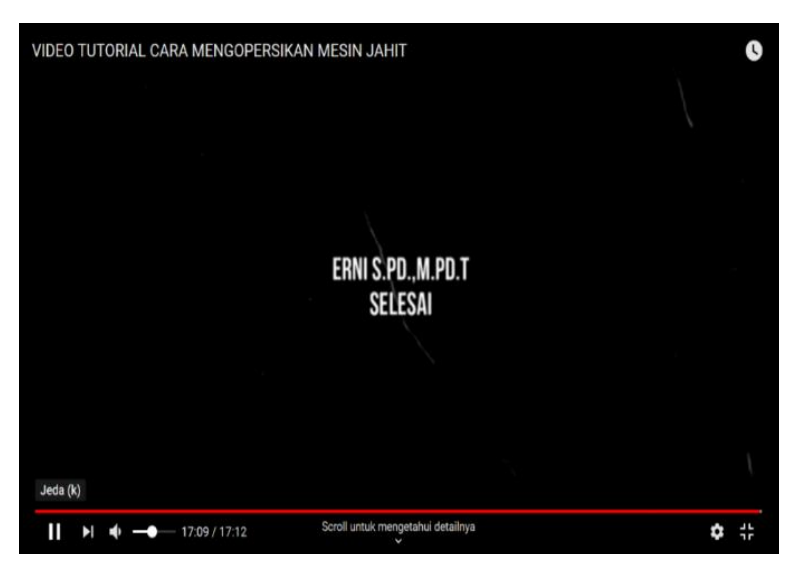

Gambar 5. Tampilan menu penutup pada video tutorial

Gambar 5 merupakan tampilan penutup video tutorial. Bagian penutup berisi harapan dosen terhadap mahasiswa dan pesan kepada mahasiswa agar tetap semangat untuk mengikuti perkulihan secara daring serta tetap mematuhi protokol kesehatan guna mencegah dan mengurangi penyebaran virus corona. Bagian penutup juga menampilkan nama pengembang video tutorial dan ucapan terima kasih. 


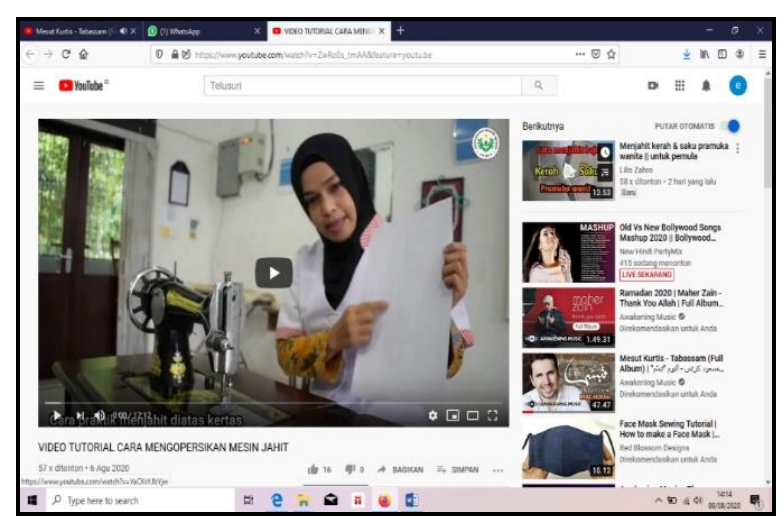

Gambar 6. Tampilan video tutorial dilayar youtube

Gambar 6 merupakan tampilan video tutorial yang telah diupload ke youtube. https://yuotu.be/ZwRo0s_tmAA. Hal ini dilakukan agar responden dapat dengan mudah mengakses video tutorial dan dapat disaksikan secara fleksibel oleh responden. Mengupload video ke youtube sesuai dengan kondisi dan situasi belajar mengajar dimasa pandemic Covid-19.

Development (pengembangan) tahap ini bertujuan untuk menghasilkan media pembelajaran yang valid, praktis dan efektif. Uji validitas dilakukan oleh ahli materi teknologi menjahit dan ahli media pembelajaran. Uji praktikalitas menggunakan angket praktikalitas dan uji efektivitas dilakukan dengan menganalisis angket motivasi belajar dan lembar pengamatan hasil belajar psikomotor mahasiswa.

a. Hasil Validasi Ahli

Pada tahap ini peneliti menentukan ahli/validator untuk melakukan uji validitas terhadap media pembelajaran berbasis video tutorial dalam mendukung pembelajaran dimasa pandemic Covid-19. Validitas media dilakukan oleh ahli materi dan ahli media. Validator yang dipilih yaitu ahli yang kompeten dibidangnya masing-masing. Revisi telah dilakukan berdasarkan penilaian dan saran yang diberikan oleh validator guna memperoleh media yang baik. Angket validasi menggunakan skala Likert dengan aspek penilaian; skor 4: Sangat Setuju (SS), skor 3: Setuju (S), skor 2: Tidak Setuju (TS), skor 1: Sangat Tidak Setuju (STS). Hasil analisis validasi media tersaji dalam tabel berikut:

Tabel 1. Hasil penilaian ahli menggunakan lembar validitas

\begin{tabular}{|c|c|c|}
\hline Aspek yang Dinilai & Skor Validasi & Ket. \\
\hline Tujuan & 3.4 & Sangat Valid \\
\hline Rasional & 3.8 & Sangat Valid \\
\hline Isi Video & 4 & Sangat Valid \\
\hline Karakteristik Video & 3.863 & Sangat Valid \\
\hline Kesesuaian & 4 & Sangat Valid \\
\hline Gambar & 3.533 & Sangat Valid \\
\hline Bahasa & 3.5 & Sangat Valid \\
\hline Bentuk Fisik & 3.7 & Sangat Valid \\
\hline Keluwesan & 4 & Sangat Valid \\
\hline Jumlah & 33.79 & \\
\hline Rata-Rata & 3.75 & Sangat Valid \\
\hline
\end{tabular}

Tabel diatas memperlihatkan semua aspek yang dinilai menunjukkan nilai kevalidan 3.75 dengan rerata $3.20-4.00$, maka aspek yang dinilai dikategorikan sangat jelas atau "sangat valid".

b. Hasil Analisi Angket Praktikalitas Mahasiswa

Pada tahap implementasi menggunakan angket praktikalitas guna mengetahuai sejauh mana respon mahasiswa terhadap media video tutorial. Lembar angket praktikalitas diberikan setelah mahasiswa menggunakan video tutorial. Adapun perhitungannya sebagai berikut: 


$$
\text { Persentase }=\frac{\text { skor } \text { yang diperoleh }}{\text { skor tertinggi }} \times 100 \%
$$

Tabel 2. Hasil penilaian ahli menggunakan lembar validitas

\begin{tabular}{ccc}
\hline Aspek yang Dinilai & Skor Praktikalitas & Kategori \\
\hline Kemudahan dalam penggunaan & 3.4 & Sangat Praktis \\
Kesesuaian dengan waktu & 3.51 & Sangat Praktis \\
Manfaat yang didapat & 3.55 & Sangat Praktis \\
\hline Rata-Rata & 3.48 & Sangat Praktis \\
\hline
\end{tabular}

Tabel diatas memperlihatkan bahwa semua aspek yang dinilai menunjukkan rata-rata nilai kepraktisan yaitu 3.48 atau $89.1 \%$ dengan kategori "Sangat praktis".

c. Hasil Analisis Efektivitas

Penilaian pada tahap efektivitas diarahkan pada penggunaan media video tutorial oleh mahasiswa. Suatu produk yang baik tentu memberi dampak yang baik pula bagi penggunanya. Efektivitas video diperoleh dengan menganalisa faktor motivasi belajar mahasiswa dan hasil belajar psikomotor. Adapun perhitungannya sebagai berikut:

$$
\text { Persentase }=\frac{\text { skor } \text { yang diperoleh }}{\text { skor tertinggi }} \times 100 \%
$$

\begin{tabular}{|c|c|c|}
\hline Indikator & Nilai Motivasi & Kategori \\
\hline Keinginan untuk belajar & 3.75 & Sangat Tinggi \\
\hline Harapan untuk berhasil & 3.46 & Sangat Tinggi \\
\hline Dorongan untuk belajar & 3.65 & Sangat Tinggi \\
\hline Ketekunan & 3.46 & Sangat Tinggi \\
\hline Rata-Rata & 3.58 & Sangat Tinggi \\
\hline
\end{tabular}

Tabel 3. Hasil analisis motivasi belajar mahasiswa

Berdasarkan tabel diatas dapat disimpulkan bahwa secara keseluruhan motivasi belajar terhadap pembelajaran menggunakan video tutorial diperoleh rerata 3.58 atau persentase $85.12 \%$. Hal ini mengindikasikan bahwa jika ditinjau dari motivasi belajar mahasiswa, maka efektivitas penggunaan media pembelajaran berbasis video tutorial berada pada kategori "Sangat tinggi".

Hasil belajar psikomotor diperoleh dengan memberikan lembar pengamatan kepada observer. Pada tahap ini observer mengamati proses kerja cara mengoperasikan mesin jahit yang dikirimkan oleh mahasiswa melalui perkuliahan daring. Observer dalam kegiatan ini yaitu dosen pengampu mata kuliah teknologi busana yang berjumlah 2 orang. Lembar pengamatan menggunakan skala Likert dengan kriteria skor 4 (dilakukan dengan baik, tepat dan teliti; skor 3 (dilakukan dengan baik dan tepat waktu dan tepat waktu); skor 2 (dilakukan dengan baik tetapi tidak tepat waktu; dan skor 1 (dilakukan dengan kurang baik). Adapun perhitungannya sebagai berikut;

Tabel 4. Hasil belajar psikomotor mahasiswa

\begin{tabular}{cccc}
\hline Praktik & Rata-Rata & Nilai & Kriteria \\
\hline $\begin{array}{c}\text { Cara mengoperasikan } \\
\text { mesin jahit }\end{array}$ & 90 & 80 & Baik \\
\hline Rata-Rata & 90 & 80 & Baik \\
\hline
\end{tabular}

Berdasarkan tabel diatas dapat disimpulkan bahwa secara keseluruhan hasil belajar psikomotor mahasiswa terhadap pembelajaran menggunakan video tutorial diperoleh rata-rata 90 dengan nilai 80. Hal ini mengindikasikan bahwa jika ditinjau dari hasil belajar psikomotor 
mahasiswa, maka efektivitas penggunaan media pembelajaran berbasis video tutorial berada pada kriteria "Baik".

Disseminate (menyebarkan) kegiatan ini dilakukan penyebar luasan produk yang telah dikembangkan dan telah teruji untuk dimanfaatkan oleh orang lain. Produk yang telah teruji validitas, praktikalitas dan efektivitas, selanjutnya produk tersebut disebarluaskan kepada dosen pengampu mata kuliah teknologi menjahit semester 1.

Research and development $(R \& D)$ atau penelitian dan pengembangan merupakan langkahlangkah dalam mengembangkan suatu produk baru atau menyempurnakan produk yang sudah ada dan dapat dipertanggung jawabkan. Disini peneliti melakukan penelitian dan pengembangan dengan membuat produk video tutorial yang valid, praktis dan efektif.

a. Validitas Media Pembelajaran

1) Hasil Validasi Ahli Materi dan ahli media.

Validasi ahli materi dilakukan oleh dua validator, salah satunya dosen pengampu mata kuliah teknologi menjahit. Uji validitas produk "video pembelajaran berbasis video tutorial pada mata kuliah teknologi menjahit dalam mendukung pembelajaran daring dimasa pandemic Covid 19", dilakukan dengan memberikan lembar validasi ahli materi dan ahli media pembelajaran yang harus diisi oleh validator.

Berdasarkan hasil validasi yang telah dilakukan oleh validator diperoleh nilai kevalidan diperoleh nilai 3.75 dengan rerata $3.20-4.00$, maka aspek yang dinilai dikategorikan sangat jelas atau "Sangat valid". Karena video pembelajaran dikemas dengan gambar-gambar menarik yang menunjukan contoh-contoh yang kongkrit untuk memperjelas materi yang di sampaikan. Pendapat ini dikemukakan oleh [13] yang menyatakan bahwa gambar mampu menyampaikan banyak makna dan memperjelas suatu pesan yang di sampaikan. Hal ini mengindikasikan bahwa produk yang telah dikembangkan valid dan layak untuk digunakan menurut ahli materi dan ahli media dalam pembelajaran daring dimasa pandemic Covid-19.

\section{b. Kepraktisan Media Pembelajaran}

Kepraktisan media pembelajaran dilakukan untuk mengetahui kepraktisan dalam penggunaan produk "media berbasis video tutorial pada mata kuliah teknologi menjahit dalam mendukung permbelajaran dimasa pandemic Covid-19". Uji kepraktisan produk tersebut dilakukan dengan memberikan angket kepraktisan yang diisi oleh 30 orang mahasiswa yang telah diberikan media pembelajaran.

Berdasarkan hasil angket praktikalitas media berbasis video tutorial diperoleh persentase $89.1 \%$ dengan kategori "Sangat praktis". Hal ini mengindikasikan bahwa media yang dikembangkan sangat praktis untuk digunakan dalam pembelajaran daring dimasa pandemic Covid-19. Hasil penelitian [14] menjelaskan bahwa media pembelajaran dapat meningkatkan minat belajar dan menjadi salah satu alternatif untuk membantu belajar mandiri mahasiswa dengan pemanfaatan video pembelajaran yang tepat. Selanjutnya [15] Pemanfaatan media pembelajaran berupa video tutorial dapat menarik minat mahasiswa dalam proses pembelajaran.

\section{c. Keefektivan Media Pembelajaran}

Keefektivan media pembelajaran bertujuan untuk mengetahui prnggunaan produk "media pembelajaran berbasis video tutorial pada mata kuliah teknologi menjahit dalam mendudkung pembelajaran daring dimasa pandemic Covid-19", efektif. Uji efektivitas produk dilakukan dengan menganalisa faktor motivasi belajar dan hasil belajar psikomotor. Analisa faktor motivasi belajar diperoleh dengan memberikan angket motivasi belajar mahasiswa. Sedangkan faktor hasil belajar psikomotor diperoleh dengan memberikan lembar pengamatan.

Berdasarkan hasil angket motivasi belajar mahasiswa menggunakan media pembelajaran berbasis video tutorial diperoleh persentase $85.12 \%$ dengan kategori "sangat tinggi". Hasil belajar psikomotor mahasiswa terhadap pembelajaran menggunakan video tutorial diperoleh rata-rata 90 dengan nilai 80 dengan kriteria "Baik". Hal ini mengindikasikan bahwa media yang dikembangkan efektif untuk digunakan dalam pembelajaran daring dimasa pandemic Covid-19.

Sejalan dengan hal ini, sebagaimana yang dikemukakan oleh [16] bahwa Media pembelajaran diikategorikan valid apabila media pada kategori baik ataupun sangat baik. Dikategorikan praktis, jika respon mahasiswa dan kegunaan media dalam pembelajaran tergolong baik, dan dikategorikan efektif apabila media yang digunakan mampu meningkatkan 
motivasi belajar dan hasil belajar mahasiswa. Selain itu terdapat beberapa hal yang menyebabkan video pembelajaran ini efektif, Mahadewi dalam [17] megemukakan bahwa "media video pembelajaran berisi bahan yang telah disusun dalam satu format sajian dengan unsur visual yang dilengkapi dengan unsur audio". keunggulan dari video pembelajaran, yaitu 1) Mampu menyajikan unsur warna, bunyi, gerakan, dan suatu proses dengan jelas, dan 2) Dapat mengkoordinasikan penggunaan berbagai media yang lain dengan baik seperti film, foto, slide, dan gambar, sehingga dapat menarik perhatian siswa sehingga dapat menumbukan motivasi belajar, memperjelas makna bahan pengajaran sehingga mudah dipahami siswa, metode pengajaran lebih bervariasi dan siswa lebih banyak melakukan kegiatan belajar.

\section{SIMPULAN DAN SARAN}

Pengembangan media berbasis video tutorial pada mata kuliah teknologi menjahit dalam mendukung pembelajaran dimasa pandemi Covid- 19 menggunakan metode 4-D yang terdiri tahap Define, Design, Development dan Disseminate telah menghasilkan media pembelajaran berbasis video tutorial yang valid, praktis dan efektif.

Media pembelajaran dapat memotivasi mahasiswa dalam belajar secara daring dan mahasiswa juga dapat mengikuti praktikum meskipun perkuliahan tidak berlangsung dilaboratorium. Produk yang dikembangkan mampu menjadi sumber belajar bagi mahasiswa dalam pembelajaran secara daring dimasa pandemi Covid-19. Media pembelajaran yang dikembangkan layak untuk digunakan sebagai panduan belajar bagi mahasiswa secara mandiri.

Berdasarkan uji validitas ahli materi dan ahli media, angket praktikalitas, angket motivasi belajar dan lembar observasi hasil belajar psikomotor yang dilakukan pada mahasiswa Program Studi Pendidikan Tata Busana, dapat disimpulkan bahwa media berbasis video tutorial pada mata kuliah teknologi menjahit dalam mendukung pembelajaran dimasa pandemic Covid-19 valid, praktis dan efektif.

Untuk pengembangan lebih lanjut disarankan untuk mengembangkan video tutorial pada beberapa materi praktikum yang memiliki potensi untuk dapat dikembangkan. Khususnya materi pada mata kuliah teknologi menjahit agar tercapainya tujuan pembelajaran yang efektif dan efisien dalam pembelajaran daring. Diharapkan pengembangan media pembelajaran menjadi penggerak bagi pendidik untuk memberikan inovasi dalam proses pembelajaran sehingga dapat menghasilkan suatu karya bagi dunia Pendidikan.

\section{DAFTAR PUSTAKA}

[1] H. H. Batubara and D. S. Batubara, "Penggunaan Video Tutorial Untuk Mendukung Pembelajaran Daring Di Masa Pandemi Virus Corona," Muallimuna J. Madrasah Ibtidaiyah, vol. 5, no. 2, p. 21, 2020, doi: 10.31602/muallimuna.v5i2.2950.

[2] Didik Haryadi Santoso; Awan Santosa, Covid-19 Dalam Ragam Tinjauan Perspektif. 2020.

[3] R. Jundu, F. Nendi, V. S. Kurnila, H. Mulu, G. P. Ningsi, and F. A. Ali, "PENGEMBANGAN VIDEO PEMBELAJARAN IPA BERBASIS KONTEKSTUAL DI MANGGARAI UNTUK BELAJAR SISWA PADA MASA PANDEMIC COVID-19," LENSA (Lentera Sains) J. Pendidik. IPA, 2020, doi: 10.24929/lensa.v10i2.112.

[4] M. Bustanil S, Asrowi, and D. T. Adianto, "Pengembangan Media Pembelajaran Interaktif Berbasis Video Tutorial Di Sekolah Menengah Kejuruan," JTP - J. Teknol. Pendidik., vol. 21, no. 2, pp. 119-134, 2019, doi: 10.21009/jtp.v21i2.11568.

[5] S. Maiyena and V. Haris, "Praktikalitas Video Tutorial pada Matakuliah Eksperimen Fisika untuk Meningkatkan Keterampilan Proses Sains Mahasiswa," J. IIm. Pendidik. Fis. Al-Biruni, 2017, doi: 10.24042/jpifalbiruni.v6i1.647.

[6] R. H. Wirasasmita and Y. K. Putra, "Pengembangan Media Pembelajaran Video Tutorial Interaktif menggunakan Aplikasi Camtasia Studio dan Macromedia Flash," EDUMATIC J. Pendidik. Inform., 2018, doi: 10.29408/edumatic.v1i2.944.

[7] N. Rusmania, "Penggunaan edmodo sebagai media pembelajaran e-learning pada mata pelajaran otomatisasi perkantoran di smkn 1 surabaya," Pengguna. edmodo sebagai media pembelajaran e-learning pada mata pelajaran otomatisasi perkantoran di smkn 1 surabaya, 2015.

[8] A. A. Gde Ekayana, "Pengembangan Modul Pembelajaran Mata Kuliah Internet of Things," J. Pendidik. Teknol. dan Kejuru., vol. 16, no. 2, p. 159, 2019, doi: 10.23887/jptk- 
undiksha.v16i2.17594.

[9] M. Mandalika and S. Syahril, "Pengembangan Media Pembelajaran Berbasis Video Tutorial untuk Meningkatkan Efektifitas Pembelajaran pada Mata Kuliah Tata Rias Pengantin Indonesia," INVOTEK J. Inov. Vokasional dan Teknol., 2020, doi: 10.24036/invotek.v20i1.725.

[10] Ummi latifatul Ummah, "Sugiyono. (2017). Metode Penelitian Pendidikan Pendekatan Kuantitatif, Kualitatif dan R\&D. Bandung: Alfabeta," Hub. intensitas Komun. dan kelekatan orang tua-anak dengan kecerdasan emosional siswa madrasah ibtidaiyah sunan kalojogo 1 tinggar, bandar kedungmulyo,jombang, 2017.

[11] R. Muhammad Aidil and Y. Gusmareta, S.Pd, M.Pd.T, "PEMBUATAN MEDIA PEMBELAJARAN BERBASIS VIDEO TUTORIAL PADA MATA KULIAH MEKANIKA TANAH DAN TEKNIK PONDASI," CIVED, 2019, doi: 10.24036/cived.v6i3.106227.

[12] L. Akhmadi, A. D. Herlambang, and S. H. Wijoyo, "Pengembangan E-Modul Pada Mata Pelajaran Komputer dan Jaringan Dasar Untuk Kelas X Program Keahlian Teknik Komputer Dan Jaringan Di SMK Negeri 2 Malang Dengan Model Pengembangan Four-D," J. Pengemb. Teknol. Inf. dan Ilmu Komput., vol. 3, no. 4, pp. 3874-3879, 2019.

[13] S. Dr. I Komang Sudarma, "Pengembangan Video Pembelajaran Dengan Bahasa Isyarat Berbasis Pendidikan Karakter Pada Siswa Kelas V Di Sdlb-B Negeri I Buleleng Tahun Pelajaran 2017/2018," J. Edutech Undiksha, 2017.

[14] T. Tafonao, "PERANAN MEDIA PEMBELAJARAN DALAM MENINGKATKAN MINAT BELAJAR MAHASISWA," J. Komun. Pendidik., 2018, doi: 10.32585/jkp.v2i2.113.

[15] M. Pritandhari and T. Ratnawuri, "EVALUASI PENGGUNAAN VIDEO TUTORIAL SEBAGAI MEDIA PEMBELAJARAN SEMESTER IV PROGRAM STUDI PENDIDIKAN EKONOMI UNIVERSITAS MUHAMMADIYAH METRO," PROMOSI (Jurnal Pendidik. Ekon., vol. 3, no. 2, Nov. 2015, doi: 10.24127/ja.v3i2.329.

[16] H. H. Al Azka, R. D. Setyawati, and I. U. Albab, "Pengembangan Modul Pembelajaran," Imajiner J. Mat. dan Pendidik. Mat., 2019, doi: 10.26877/imajiner.v1i5.4473.

[17] P. D. Wisada, I. K. Sudarma, and A. I. W. I. Yuda S, "PENGEMBANGAN MEDIA VIDEO PEMBELAJARAN BERORIENTASI PENDIDIKAN KARAKTER," J. Educ. Technol., 2019, doi: 10.23887/jet.v3i3.21735. 